\title{
Rare colour aberration in the short-tailed fruit bats (carollia perspicillata)
}

\begin{abstract}
We presented a new report of one species of albino short-tailed fruit bats Carollia perspicillata, from Villanueva Casanare, Colombia. These samples represented the first time this kind of atypical phenomenon has been recorded on Colombia. These specimens differ from other individuals due to the irregular distribution of melanin pigments in their ventral and dorsal hair. Only two specimens of C. perspicillata albinos have been previously registered in Brazil.
\end{abstract}

Keywords: albino, carollinae, colombia
Volume 2 Issue | - 2018

\author{
Alexis Calderón-Álvarez R,' Anatoly Marin- \\ Vasquez $^{2}$ \\ 'Fundación para la Investigación en Biodiversidad Amazonica - \\ FIBA, Colombia \\ ${ }^{2}$ University of Applied and Environmental Sciences UDCA, \\ Colombia
}

Correspondence: Anatoly Marin-Vasquez, MSc Ciencias Ambientales, University of Applied and Environmental Sciences UDCA, DC Ara Corporation of the Amazon - ARACORP, Bogotá, Colombia, Email anatoly.marin.vasquez@gmail.com

Received: November 15, 2017 | Published: February 07, 2018

\section{Introduction}

The occurrence of aberrant colorations such as melanism, leucism or albinism is rare in bats. ${ }^{1}$ In bats, mainly melanism or leucism (also described as isabellinism) have been reported. ${ }^{1-17}$ Albinism, ${ }^{18}$ a complete loss of all pigment in coat and other body parts, is the most severe aberration in coloration patterns. It results with white coat colour and lack of pigment in soft parts ${ }^{18,19}$ and is very rarely recorded in natural populations. ${ }^{1}$ Here, we report the first observation of an albino Short-Tailed Fruit Bats Carollia perspicillata from Colombia. Carollia perspicillata is distributed from Colombia eastward across northern South America, including Trinidad and Tobago, and southward into Bolivia, Paraguay, southern Brazil, and northern Argentina. The species also is known from the Isthmus of Tehuantepec, Mexico, southward throughout Central America. ${ }^{20}$

Our observations were made on Villanueva Casanare

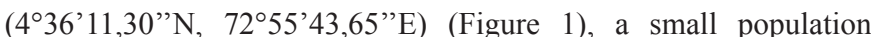
located 129,84km off the Bogotá Colombia, during fieldwork on bats between 10 and 20 August 2013. Short-Tailed Fruit Bats were breeding in large colonies on the municipality (an estimated 30-50 breeding pairs, scientific staff, government service for rural development pers. comm.) rearing small to large juveniles and adults specimens.

While we were on the municipality, we viewed and photographed colonies of Short-Tailed Fruit Bats twice a day from a fixed point (lighthouse), to avoid disturbing them. The albino individual was noticed while checking breeding colonies with binoculars and photographed. Its coat color was pure white, without any pigmentation (Figure 2). The skin, ears, nose leaf, and eyes lacked any pigmentation, resulting in a pink colour. The individual was an adult, with sibling and parents presenting the classical coat color of the species. The individual seemed in good condition. We observed the regular behavior of the population followed by food, and did not note any apparent conflict between this albino individual and its con specifics.

To our knowledge, our observation represents the first reported case of albinism (pure albinos sensu ${ }^{18}$ ) for this species from Colombia, despite the permanent field presence and weekly visits to the large Short-Tailed Fruit Bats colonies by wardens of the municipality over many years (scientific staff, government service for rural development pers. comm.). This is the first case reported for Colombia and third of South America: ${ }^{1,16,17}$ our observations involved adult individuals. Juveniles albinos have not been reported for the species, nor is there any mention of albinism in the Short-Tailed Fruit Bats in the literature, suggesting that this trait is very uncommon. The rarity of albinism may result from a higher mortality rate from predators and difficulty in obtaining a mate. ${ }^{1,19}$ Furthermore, albino individuals can be difficult to detect due to very large size of the colonies (Figure 2).

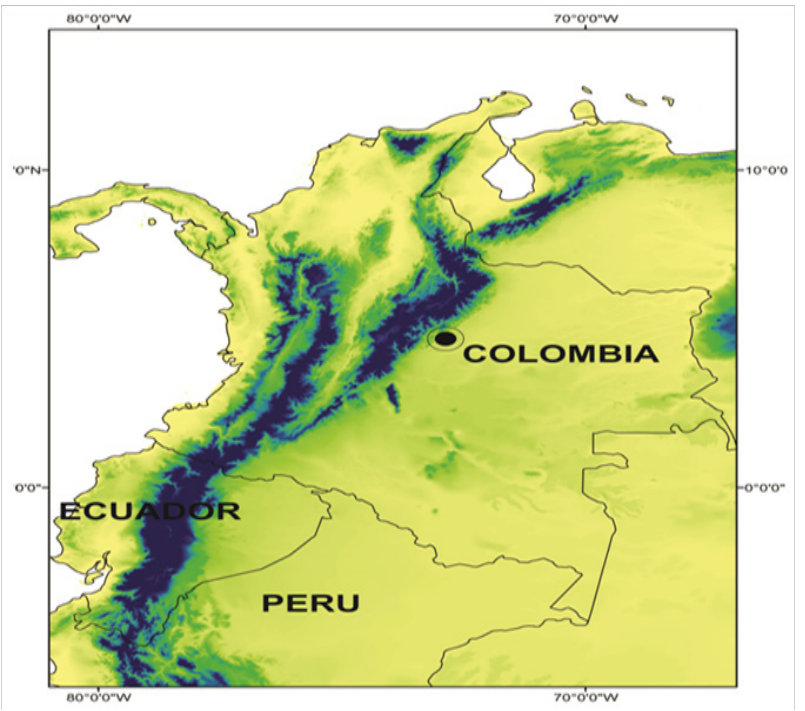

Figure IThe black point represents the locality of study Short-Tailed Fruit Bats Carollia perspicillata from Colombia.

Among Phyllostominae and Molossidae, albinism has been reported for the species: Artibeus planirostris, C. perspicillata, Dermanura cinerea, Desmodus rotundus, Glossophaga longirostris, Sturnira erythromos, Uroderma bilobatum, Eumops glaucinus, and 
Molossus molossus. ${ }^{1,2,4-8,16,17,21}$ According Marin-Vasquez et al. ${ }^{10}$ some of these reports represent cases of leucism or these authors used leucism as a synonym for partial albinism of C. perspicillata: Brazil ${ }^{15}$ Ecuador, ${ }^{9}$ Frech Guiana. ${ }^{3}$

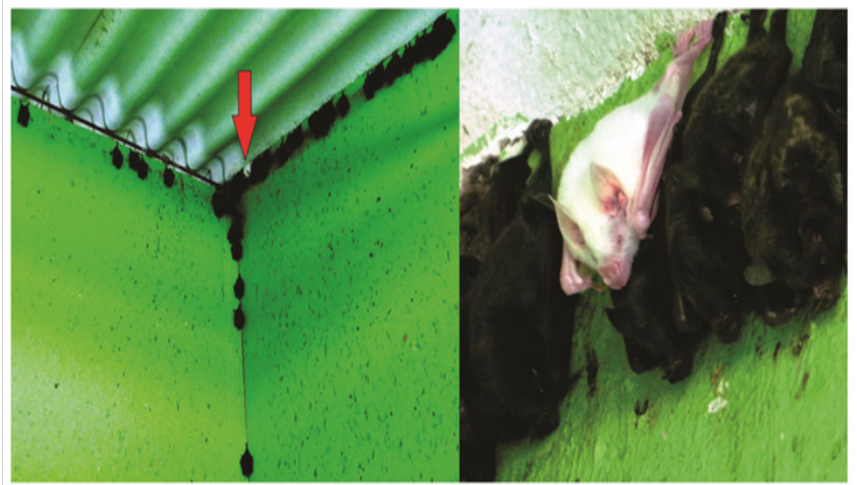

Figure $\mathbf{2}$ General view of a small part of the colony of Short-Tailed Fruit Bats Carollia perspicillata with the albino on Villanueva, and Close-up of the albino Short-Tailed Fruit Bats.

\section{Conclusion}

The cause of variation in the incidence of albinism among families is unknown but "it ... appears to be in species that are both social in their breeding habits and also fairly sedentary", ${ }^{13,19,21}$ conditions that increase the chances of mating between individuals heterozygous for albinism. Uieda ${ }^{1}$ noted that albinism is seldom found in bats roosting in unsheltered places. This might imply that the survival rate of albino bats in sheltered roosts. Albinism is known to have a genetic basis, and others factors such as diet or trauma are of minor significance. ${ }^{19}$ A more plausible explanation is that both parents possessed an albino allele, as hereditary albinism is generally a recessive character.

\section{Acknowledgements}

We thank Government Service for Rural Development for giving us permission to work on Villanueva. We thank two anonymous referees for useful suggestions to improve the manuscript. Anatoly were supported by Bureau Agriculture of Caqueta, and Misión Verde Amazonia, and ARACORP.

\section{Conflict of interest}

Author declares there is no conflict of interest in publishing the article.

\section{References}

1. Uieda W. A review of complete albinism in bats with five new cases from Brazil. Acta Chiropterologica. 2000;2(1):97-105

2. Soriano P, Utrera A, Sosa M. Two records of albino bats for Venezuela. Biollania. 1993;9:149-150.

3. Charles-Dominique P, Brosset A, Jouart S. Bat Atlas of Guyana. Paris National Museum of Natural History Natural Heritage. 2001;49:172.

4. Barquez RM, Carrrizo LV, Ferro LI, et al. Primer caso de albinismo total para Sturniraerythromos (Tschudi, 1844) (Chiroptera: Phyllostomidae) Chiroptera Neotropical. 2003;9:166-169.
5. Sodré MM, Uieda W, Baldim M. First record of albinism in the bat $E u$ mops glaucinus (Molossidae) from Southeastern Brazil. Chiroptera Neotropical. 2004;10(1-2):200-201.

6. Geiger D, Pacheco SM. Record of partial albinism in Nyctinomops laticaudatus (E. Geoffroy, 1805) (Chiroptera: Molossidae) in southern Brazil. Chiroptera Neotropical. 2006;12(1):250-254.

7. Oliveira HFM, Aguiar LMS. A new case of complete albinism in bat from Brazil. Chiroptera Neotropical. 2008;14(2):421-423.

8. Roncancio N, Ramírez-Chaves HE. Registration of leucism in Sturnira erythromos in the central Andes of Colombia. Chiroptera Neotropical. 2008;14(2):412-414

9. Boada C, Tirira D. First record of partial albinism (leucism) in Carollia perspicillata (Phyllostomidae) in Ecuador. Chiroptera Neotropical. 2010;16(2):755-757.

10. Marin-Vasquez A, Ortega-Rincón M, Ramírez-Chaves HE. Records of leucism in three species of Colombian bats: Carollia brevicauda, Artibeus jamaicensis and Lophostoma silvicolum (Phyllostomidae). Chiroptera Neotropical 2010;16(2):706-709.

11. Miranda JMD, Kaku-Oliveira NY, Munster LC, et al. First data of a reproductive colony of Myotis levis (I. Geoffroy, 1824) in the fields of Palmas, Paraná, Brazil (Vespertilionidae). Chiroptera Neotropical 2010;16(2):762-768.

12. Idoeta FM, de Santis LJM, Barquez RM. Leucism in Eptesicus furinalis (d'Orbigny and Gervais, 1847) (Chiroptera: Vespertilionidae) in the province of Corrientes, Argentina. Chiroptera Neotropical. 2011;17(2):985-988.

13. Sánchez-Hernández C, Rojas-Martínez A, López-Vidal JC, et al. Leucism in five species of bats from Mexico. Chiroptera Neotropical. 2012;18(2):1123-1127.

14. Marin-Vasquez A, González-Ibarra I, Gualy L, et al. Aberrations in coat color pattern of colombian bats: isabelline, leucism and melanocytes nevus. Journal Online BioScence and Informatics. 2013;4(3):253-265.

15. Rocha AP, Feijó JA, Ramos Donato C, et al. Partial albinism (Leucism) in Seba's short-tailed bat, Carollia perspicillata (Linnaeus, 1758), from a rock shelter in northeastern Brazil. Chiroptera Neotropical. 2013;19(1):1151-1153.

16. Falcão FC. First record of complete albinism in Carollia perspicillata (Chiroptera, Phyllostomidae). Chiroptera Neotropical. 2014;20(1):1234-1236.

17. Ruckert da Rosa A, Alves Martorelli LF, Fernandes de Almeida M, et al. Albinism in Carollia perspicillata (Chiroptera; Phyllostomidae), in the state of Rondônia, Brazil. A brief review of albinism in bats. Biotemas. 2017;30(3):71-77.

18. Van Grouw H. Not every white bird is an albino: Sense and nonsense about colour aberrations in birds. Dutch Birding. 2006;28:79-89.

19. Sage BL. The incidence of albinism and melanism in British birds. British Birds. 1963;56:409-416.

20. McLellan LJ, Koopman KF. Subfamily Carolliinae. In: Gardner LA, editors. Mammals of South America, Marsupials, Xenarthrans, Shrews, and Bats. The University of Chicago Press, Chicago, USA, 2007. p. 208-218.

21. Mantilla-Meluk H, Jiménez-Ortega AM. First case of albinism in and its implications in the evolution of coat color patterns among Vampyressine bats. Investigación Biodiversidad \& Desarrollo. 2011;97-100. 